\title{
Dissolved organic carbon vertical movement and carbon accumulation in West Siberian peatlands
}

\author{
Evgeny A. Zarov ${ }^{1}$, Elena D. Lapshina ${ }^{1}$, Iris Kuhlmann² ${ }^{2}$ Ernst-Detlef Schulze ${ }^{2}$ \\ ${ }^{1}$ UNESCO chair «Environmental dynamic and global climate changes», Yugra State University, \\ 5 Khanty-Mansiysk, 628012, Russian Federation \\ ${ }^{2}$ Max Planck Institute for Biogeochemistry, P.O. Box 100164, 07701 Jena, Germany \\ Correspondence to: Evgeny A. Zarov (zarov.evgen@yandex.ru)
}

\begin{abstract}
Dissolved organic carbon is an additional path of carbon cycle but there is a lack of information about its distribution in peatland and rates of downward movement. We dated seven peat cores (separately the dissolved (DOC) and particulate (POC) organic carbon) from Mukhrino peatland (typical zonal oligotrophic bog) in western Siberia to assess the date distribution between those two peat fractions. Our results revealed that the DOC is younger than POC for the surface peatland layers $(0-150 \mathrm{~cm})$ and older for the deeper layers. The date differences increases with depth and reaches 2000-3000 years at the bottom layer $(430-530 \mathrm{~cm})$. In our hypothesis this date

15 discrepancy caused by more young DOC moving to the deeper and older peat layers. The estimated average value of DOC downward movement was $0.047 \pm 0.019 \mathrm{~cm} \mathrm{yr}^{-1}$.

Th oldest dates found at the lake bottom and ancient riverbed were 10053 and $10989 \mathrm{cal} \mathrm{yr} \mathrm{BP}$ correspondingly. For the whole period of peatland functioning the average peat accumulation rate was estimated as $0.067 \pm 0.018 \mathrm{~cm} \mathrm{yr}^{-1}\left(0.013-0.332 \mathrm{~cm} \mathrm{yr}^{-1}\right)$, the carbon accumulation rate was estimated as $38.56 \pm 12.21 \mathrm{~g} \mathrm{C} \mathrm{m}^{-2} \mathrm{yr}^{-1}\left(28.46-57.91 \mathrm{~g} \mathrm{C} \mathrm{m}^{-2} \mathrm{yr}^{-1}\right)$.
\end{abstract}

\section{Introduction}

Peatlands unlike the most other ecosystems assimilate carbon and sequestrate it over thousands years as long as net primarily production exceeds the rate of organic matter decomposition. It has

25 been estimated that peatlands occupy about $2.84 \%$ (4.23 million sq. $\mathrm{km}$.) of global land area $(\mathrm{Xu}, 2018)$ but have accumulated disproportionally huge amount of world soil carbon $(\sim 30 \%)$ (Yu, 2014).

West Siberia is the world's largest wetland where peatlands cover $50-75 \%$ of whole area (Peregon, 2008) that makes this territory one of the most waterlogged place in the world. Peatlands

30 occupy here not only local relief depressions but also vast watershed areas and floodplains (Bleuten and Lapshina, 2001). The West Siberian peatlands are estimated to contain $\sim 20 \%$ of world peat 
deposits with the highest coverage percent in the taiga zone (Kremenetski, 2003; Sheng, 2004) having a carbon stock of $70.2 \mathrm{Pg}$ (up to $\sim 26 \%$ of all terrestrial carbon) (Smith, 2004).

Carbon sequestration by peatlands and losses through surface runoff and greenhouse gases emission are strongly correlated to the climate conditions (Baird et al., 2013). Part of litter and peat convert to dissolved form (so-called dissolved organic carbon, DOC) when in contact with exo-enzymes of microorganizms and acidic peatland water (Aravena et al., 1993; Charman et al., 1994,1999; Chasar et al., 2000; Clymo and Bryant, 2008, Schulze et al., 2015; Bleuten et al., 2020).

The release of DOC to streams and rivers is a characteristic phenomenon of peatland landscapes

40 (Frey and Smith, 2005). DOC discharging into surface water from the upper peatland layers derived from recently fixed C ( $\sim 50$ years) (Billett et al., 2007). However, there is also old DOC flowing vertically up and down in the peat profile and its proportion is still unclear. Expected global warming may cause elevated concentrations of DOC discharge to the streams and significantly increase DOC flux to the Arctic Ocean (Freeman et al., 2004).

45 The process of DOC downward movement may lead to the mixing of young and old $\mathrm{C}$ and therefore dating inversions. There are several well-known possible reasons causing such inversions, such as roots intrusion (Glaser et al. 2012), slipping from the neighboring peat (Jaworski and Niewiarowski, 2012), peat fires (Turetsky et al., 2011) and other profile disturbances (Kołaczek, et al., 2019) such as dry years, cryoturbation, periodical flooding or other factors (Väliranta, et al., 2014). Usually the

50 inversed dates are excluded from the age-depth model which may lead to the significant shift of the model shape and different interpretation scenarios (Lamentowicz et al., 2015; Kołaczek, et al., 2019). All mentioned reasons happen occasionally, while the DOC flux is expected to be permanent and causes an error of under- or overestimation of the sample date. In this study we focus on the effects of a slow vertical downward movement of water. Our data may help to increase accuracy of

$55{ }^{14} \mathrm{C}$ dating and to give a possible explanation of outliers in the age-depth models.

In this research we aim: (1) to show differences between dating of dissolved and particle organic carbon; (2) to estimate a velocity of DOC downward movement; (3) to assess the peat and carbon accumulation rates.

Our hypothesis is that DOC flows down into the mineral base sediment has a younger age and thus 60 may cause inversion of dating of bulk samples.

\section{Study site}

\subsection{Peatland location}

Mukhrino peatland is located in the middle taiga zone (Gvozdetskii et al., 1973) of West Siberia near by the confluence of two huge rivers Irtysh and Ob' (60.889 N, $68.702 \mathrm{E})$. It occupies a local 
65 watershed between two small rivers "Mukhrina" and "Bolshaya rechka" on the left terrace of Irtysh River (Fig. 1. cores_location.png). This is a zone of oligotrophic (rain fed) raised Sphagnum bogs (Ivanov and Novikov, 1976). The total Mukhrino peatland area is $65 \mathrm{~km}^{2}$ which is operated by the Mukhrino field station (UNESCO Chair of Environmental Dynamic and Global Climate Changes, Yugra State University) and situated in $20 \mathrm{~km}$ south-west from Khanty-Mansiysk city.
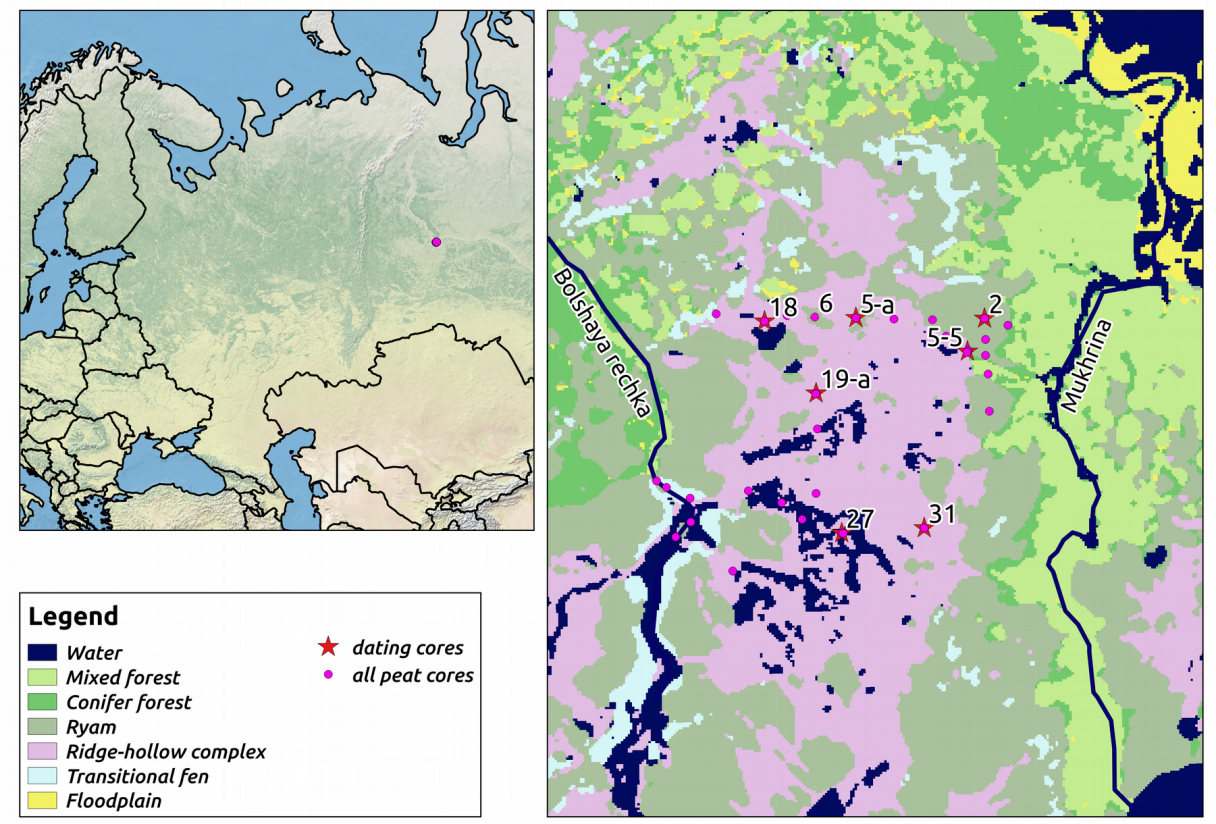

Figure 1: Location of the Mukhrino field station and all cores.

\subsection{Climatic conditions}

Climate of the region is moderately continental. According to the data of the station of the Russian Weather Service at Khanty-Mansiysk the annual air temperature is $-0.9^{\circ} \mathrm{C}\left(-1.0^{\circ} \mathrm{C}^{* 1}\right)$ with a cold winter with the mean January temperature $-20.0 \mathrm{C}\left(-21.5^{\circ} \mathrm{C}^{*}\right)$ and a short summer with the mean July temperature $18.2 \mathrm{C}\left(17.4^{\circ} \mathrm{C}^{*}\right)$. Mean annual amount of precipitation is $533 \mathrm{~mm}(480 \mathrm{~mm} *)$ with the most of this volume $314 \mathrm{~mm}(307 \mathrm{~mm}$ ) falling at the summer-autumn season (mostly in August-September). The rest of precipitation is snow which appears at the end of October, starts melting in the mid of April and completely disappears in May. The area is characterized by the absence of permafrost, but spots of frozen soil on the depth 50-100 cm might be found till the end of June.

1Values calculated on the base of measurements at the Mukhrino field station for the 2009-2020 years (Dyukarev et al., 2021). 


\subsection{Vegetation}

The peatland is surrounded by taiga forest dominated by Pinus sibirica, Picea obovata, Abies sibirica mixed with Populus tremula, Betula pubescens, occupying the mineral islands and up-land slopes along the rivers and streams.

The main peatland vegetation unit types are:

Pine-dwarf shrub-peat moss community, so-called "ryam", typical ryam is characterized by low Scotish pine leyer (Pinus sylvestris f. litwiniwii, 1.5-4 m height), well developed dwarf shrub layer (Ledum palustre, Chamaedaphne calyculata), and dominance of Sphagnum fuscum in moss layer

90 with minor admixture by S. angustifolium and S. divinum;

Tall ryam with similar to the typical ryam vegetation but with tall pine trees (Pinus sylvestris $\mathrm{f}$. uliginosa, 6-10 m height) and Sphagnum angustifolium dominance in moss layer. Tall ryam occupies shallow peat deposits on the peatland outskirts.

Ridge-hollow complex featured by alternating typical ryam communities occupying elongated across water flow ridges and waterlogged sedge-peat moss hollows (Carex limosa, Scheuchzeria palustris, Eriophorum russeolum, Sphagnum balticum, S. majus, S. jensenii);

Treeless through flow fens and Sphagnum lawns with hollow vegetation and rare scattered hummocks are developed within limited areas in the lower reaches of the peatland water catchment (Filippov and Lapshina, 2008).

100 Peatland has a dome shape with the difference in elevation between the edge and central parts in 1.2 meters (Bleuten et al., 2020). Central part is occupied by ridge-hollow complex; at the edge it becomes more inclined and drained letting the ryam and tall-ryam communities grow.

\subsection{Peatland stratigraphy}

Mukhrino peatland has been initiated as a minerotrophic fen with dominance of trees (birch, pine,

105 fir) and herbs (fern, horse-tail and tussock-forming sedges). Remains of these plants form the bottom layer of minerotrophic peat covering whole area of the peatland. Its thickness does not exceed $1.7 \mathrm{~m}$ and is $0.65 \mathrm{~m}$ in average. A thin layer $(\sim 0.5 \mathrm{~m})$ of transitional peat formed by mesotrophic plant remains (Scheuchzeria palustris, sedges, dwarf shrubs and Sphagnum mosses) overlays the bottom peat layer. Oligotrophic peat forms the main upper part of peatland body. About

$1102 / 3$ of peat deposit is composed of Sphagnum peat with the interlayer of thin cotton-grassSphagnum or sedge-Scheuchzeria-Sphagnum peat types, as formed by dynamic changes of the ridge-hollow complex.

The most abundant peat types are Sphagnum fuscum-peat (share in the structure of the peat deposit 22.5\%), Sphagnum hollow peat (S. balticum, S. papilosum (12.0\%)) and mixed Sphagnum oligotrophic peat ( $S$. fuscum, S. angustifolium, S. divinum, S. papillosum, S. balticum (5.7\%)). 


\subsection{Peatland hydrology}

Mukhrino peatland is fed by the rain and melt snow water. The highest water level is coincided with the snow melt at the end of April - beginning of May. Usually melt water is kept on the peatland surface in local depressions or blocked by ridges until the upper peat layer melt down. In that time all water rapidly seeps into the peatland, dramatically increasing water level. The lowest water level is recorded at the end of summer time (usually in August) then water table rise up because of intense autumn precipitation and low air temperature decreasing an evapotranspiration. Discharge from the streams stops at the mid of October when water freezes. For more information see (Bleuten et al., 2020).

\section{Materials and methods}

\subsection{Field sampling}

In summer 2016, a total of 7 peat cores (Table 1) were extracted through the entire depth of peatland with a Russian corer $(5.0 \mathrm{~cm}$ inside diameter, $0.5 \mathrm{~m}$ sampling step). Each half-meter part was moved to the plastic cassette, wrapped in stretch-film, transported to the laboratory (Yugra State

130 University) and subdivided into 10-cm subsamples for the further analysis. In the field 68 samples of $1 \mathrm{~cm}$ thick were cut from the bottom of each half-meter of 7 peat cores for the AMS radiocarbon analysis. With minimum contact to the environmental to avoid contamination it has been moved to the plastic zip-bags, labeled and sent to the Max-Plank Institute of Biogeochemistry in Jena (Germany).

135

Table 1. Peat sampling point description

\begin{tabular}{|c|c|l|c|c|}
\hline N & Core title & \multicolumn{1}{|c|}{ Habitat description } & $\begin{array}{c}\text { Water table, } \\
\mathrm{cm}\end{array}$ & $\begin{array}{c}\text { Peat depth, } \\
\mathrm{cm}\end{array}$ \\
\hline 1. & Core 2 & $\begin{array}{l}\text { Typical ryam - dry peatland merge; covered by pine trees } \\
\text { (up to 3 m high), Ericaceae dwarf shrubs and Sphagnum } \\
\text { fuscum }\end{array}$ & $20-30$ & 530 \\
\hline 2. & $\begin{array}{l}\text { Core 5 } \\
\text { Core 19 }\end{array}$ & $\begin{array}{l}\text { Ridge in ridge-hollow complex; covered by low pine (up to } \\
\text { 2 m high), Ericaceae dwarf shrubs and Sphagnum fusum }\end{array}$ & $15-20$ & 390 \\
\hline 3. & Core 5-5 & $\begin{array}{l}\text { Ecotone between ridge and hollow; covered by mixed } \\
\text { species from both habitats: cotton-grass, Sphagnum mosses } \\
\text { (S. fusum, S. balticum), Ericaceae dwarf shrubs }\end{array}$ & $5-10$ & 310 \\
\hline 4 & Core 18 & $\begin{array}{l}\text { Floating Sphagnum mat close at the lake; covered by } \\
\text { Scheuchzeria, sedges (Carex limosa), Sphagnum mosses (S. } \\
\text { pappilosum, S. balticum) }\end{array}$ & $2-5$ & 480 \\
\hline 5 & Core 27 & $\begin{array}{l}\text { Ridge in ridge-pool complex; treeless ridge with dwarf } \\
\text { shrubs and Sphagnum mosses }\end{array}$ & $10-15$ & 400 \\
\hline 6 & Core 31 & $\begin{array}{l}\text { Hollow in ridge-hollow complexes; covered by sedges } \\
\text { (Carex limosa) and Sphagnum balticum }\end{array}$ & $5-10$ & 380 \\
\hline
\end{tabular}


For the description the peatland stratigraphy additionally 34 peat cores has been collected for the period 2010-2016 (Fig. 1).

\subsection{Plant macrofossils}

Plant macrofossil was analyzed in each 10 -cm subsample. For that a piece of $\sim 10 \mathrm{~cm}^{3}$ was sieved through $0.25 \mathrm{~mm}$ mesh under flowing water. Plant remains were identified under the binocular microscope (Zeiss Axiostar, 10-40×magnification, Jena, Germany) using both our own experience and the key samples data bank. Peat content was described as abundance of each type of plant remains in percepts, and dominated species remains in a sample determined a peat type.

\subsection{Bulk density, carbon and ash content}

Bulk density, carbon and ash content were determined for each $10 \mathrm{~cm}$ subsample using the middle part of $5 \mathrm{~cm}$ length (volume $50 \mathrm{~cm}^{3}$ ). Bulk density (BD: $\mathrm{g} \mathrm{cm}^{-3}$ ) was measured by drying the peat at $105^{\circ} \mathrm{C}$ for 24 hours and later weighting. The dried subsample was grinded and divided into two parts. Ash content was determined from one part by ignition (Nabertherm L9/11/SKM, Lilienthal, Germany) at $525^{\circ} \mathrm{C}$ for 9 hours, and a carbon content was determined in the other part. In the elemental analyzer (EA-3000, EuroVector, Pavia, Italy) sample combusted in the oxygen and helium flow on the $\mathrm{Ni} / \mathrm{Cu}$ catalysts and separates on the chromatography column. Elements are identified on the thermal conductivity detector using Atropine $(\mathrm{C}=70.56 \%, \mathrm{~N}=4.84 \%, \mathrm{H}=8.01 \%$, $\mathrm{O}=16.59 \%$ ) as a standard.

155 Bulk density and ash content have been defined only for the cores 5a, 5_5, 19a, 27, carbon content for the cores 2, 5a, 5_5, 19a.

\subsection{Accumulation rates and dissolved organic carbon downward velocity calculations}

Peat accumulation rate (A) was calculated for each $50 \mathrm{~cm}$ part (or more in case of a dating lack) using the next Eq. (1):

$$
A=\left(d_{l}-d_{u}\right) /\left(a_{l}-a_{u}\right),
$$

where A - peat accumulation rate, $\mathrm{cm} \mathrm{y}^{-1}, \mathrm{~d}_{1}$ - lower dated depth, $\mathrm{d}_{\mathrm{u}}$ - upper dated depth, $\mathrm{a}_{1}$ - the date of lower depth, $\mathrm{a}_{\mathrm{u}}$ - the date of upper depth.

Carbon accumulation rate (CAR) was calculated for each $10 \mathrm{~cm}$ part using Eq. (2):

$C A R=\left(\left(V^{*} B D^{*} L O I / 100\right) * C C / 100\right) /\left(10 / A_{i}\right)$,

165 where CAR - carbon accumulation rate, $\mathrm{g} \mathrm{C} \mathrm{m}^{-2} \mathrm{y}^{-1}, \mathrm{~V}$ - volume of peat $10000, \mathrm{~cm}^{3}$ (i.e. $1 \mathrm{~m}^{2}$ of 10 cm depth), BD - bulk density, $\mathrm{g} \mathrm{cm}^{-3}$, LOI - loss on ignition, $\%, \mathrm{CC}$ - carbon content, $\%, 10 / \mathrm{A}_{\mathrm{i}}-$ years to grow $10 \mathrm{~cm}$ of peat, years. 
For carbon accumulation rate calculations for cores 2, 18, 27, 31 were used the mean values of necessary properties based on statistical analysis of all analyzed cores from the Mukhrino mire.

$\mathrm{LORCA}=\mathrm{CAR}_{\text {cumulative }} / \mathrm{A}_{\text {bottom }}$,

where LORCA - long term rate of carbon accumulation, $\mathrm{g} \mathrm{C} \mathrm{m}^{-2} \mathrm{yr}^{-1}, \mathrm{CAR}_{\text {cumulative }}$ - cumulative carbon storage in a square meter in the core, $\mathrm{g} \mathrm{C} \mathrm{m}^{-2}, \mathrm{~A}_{\text {bottom }}-$ the bottom age of the core, years. DOC downward movement velocity was calculated The next Eq. (4) has been used:

$175 v=\left(d_{i}-d_{i-1}\right) /\left(a_{p o c}-a_{d o c}\right)$,

where $v$ - DOC movement velocity, $\mathrm{cm} \mathrm{yr}^{-1}, \mathrm{~d}_{\mathrm{i}}-$ depth of current DOC age, $\mathrm{cm}, \mathrm{d}_{\mathrm{doc} \_\mathrm{i}}-$ POC depth of the same age as a current DOC, $\mathrm{cm}, \mathrm{a}_{\mathrm{poc}}-$ age of POC on the current depth, years, $\mathrm{a}_{\mathrm{doc}}-$ age of DOC on the current depth, years.

\subsection{Separation of DOC and POC}

180 Using the approach from (Schulze, et al., 2015) it is possible to separate the DOC from the POC by dispersing the peat sample in distilled water. First the frozen peat sample was thrown carefully, weighed, dissolved in distilled water and shaked for 2 hours. The solution was wet-sieved with a 63 and $36 \mu \mathrm{m}$ mesh sieve. The residues from the sieve were freeze dried (Piatkowski, Munich, Germany). The sieved solution $(<36 \mu \mathrm{m})$ was adjusted to $\mathrm{pH} 9$ by adding $\mathrm{NaOH}$, shaked another 20

185 Minutes and centrifuged at $2900 \mathrm{~g}$ for $30 \mathrm{~min}$ (Megafuge 3.0, Heraeus, Hanau, Germany). The obtained supernatant was filtered with a vacuum flask using a $1.6 \mu \mathrm{m}$ glass fiber filter (Sartorius) which has been baked at $500^{\circ} \mathrm{C}$ beforehand. The filtered matter $<1.6 \mu \mathrm{m}$ was freeze dried and defined as dissolved organic matter (DOC).

The filter residues $>1.6$ and the pellet remaining from the centrifugation $<36 \mu \mathrm{m}$ were merged and freeze-dried. This fraction $(>1.6,<36 \mu \mathrm{m})$ was defined as particulate organic matter (POC).

\subsection{AMS $14 \mathrm{C}$ analysis}

The peat core DOC and POC samples were analyzed with the Accelerator Mass Spectrometer (AMS) radiocarbon $\left({ }^{14} \mathrm{C}\right)$ method (Steinhof, 2016, 2017).

For one measurement $0.7 \mathrm{mgC}$ is needed. The Samples pass a chemical preparation whereby the

sample was combusted and the emerged $\mathrm{CO}_{2}$ trapped and catalytically reduced to graphite under presence of $\mathrm{Fe}^{2+}$ powder and $\mathrm{H}_{2}$. The resulting graphite was pressed into targets and finally measured in the AMS system. The graphite was ionized in the AMS system (negative charge) and accelerated within an electric field to a final energy of $400 \mathrm{keV}$. The ${ }^{14} \mathrm{C}$ isotope ratios was been corrected with the measured 13/12C AMS values (Steinhof, 2017). The radiocarbon dates were 
200 calibrated (Appendix. Table A1) with the IntCal20 (Reimer et al., 2020) and NH1 post-bomb (Hua et al., 2013) atmospheric curves using the package 'clam' (Blaauw, 2020). The age-depth model was developed using the Bayesian-based package 'rbacon' (Blaauw et al., 2020) with $95 \%$ confidence intervals.

\section{Results}

\subsection{Peat stratigraphy profile, ages and accumulation rate}

Average peatland depth based on 35 cores is $340 \mathrm{~cm}$ ranging from 85 till $530 \mathrm{~cm}$ (Fig. 2 . age_depth_cores.png). Two deepest points were found at the northern part of the peatland: the western point is a depression of primary lake (Core 18; $480 \mathrm{~cm})$ partly covered by gyttja $(100 \mathrm{~cm})$ and peat $(380 \mathrm{~cm})$; the point on the east (Core 2; $530 \mathrm{~cm})$ is associated with an ancient streambed rush-peat at the bottom. Other cores have minerotrophic grass-woody peat at the bottom $(40-60 \mathrm{~cm})$ and have depth till $350-400 \mathrm{~cm}$.

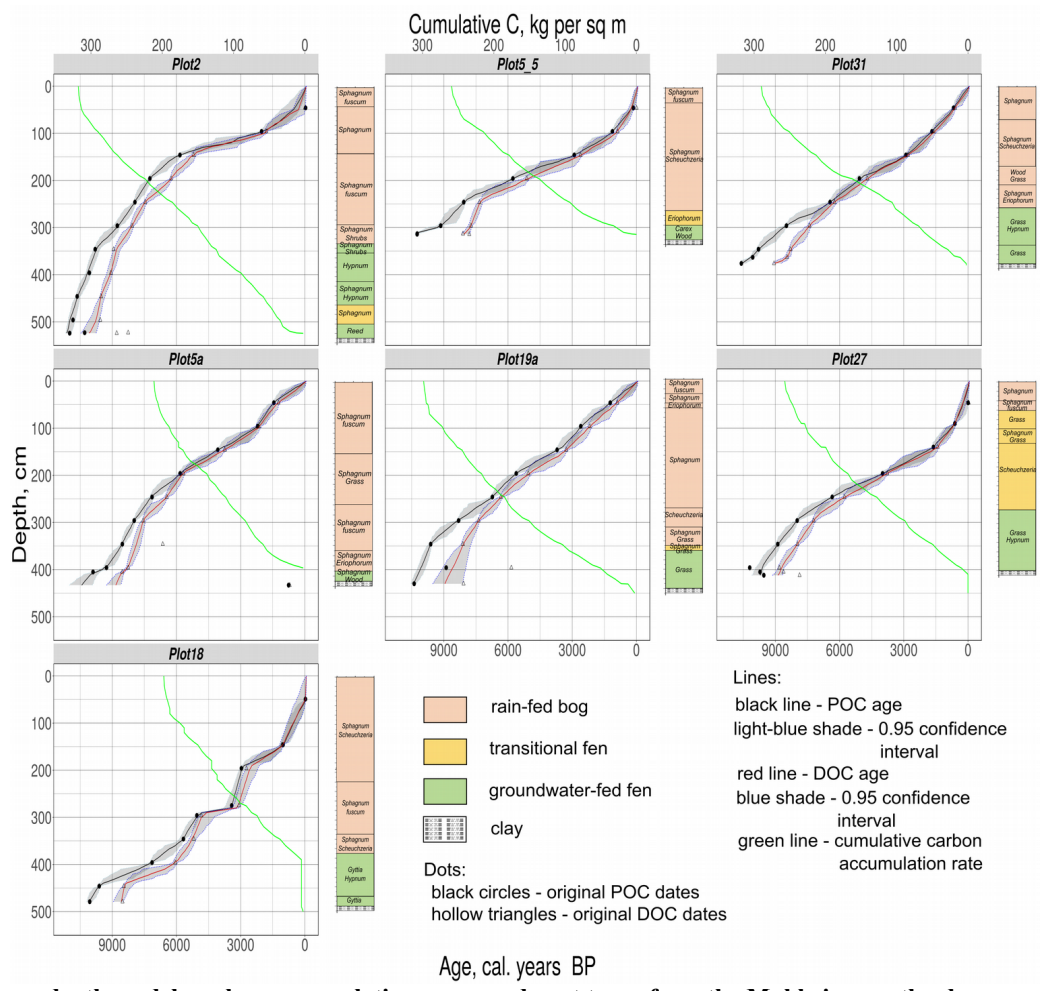

Figure 2: The age-depth model, carbon accumulation curve and peat types from the Mukhrino peatland. 
215 Shallow peat deposits $(\sim 100 \mathrm{~cm}$ and less $)$ are presented on the peatland edge at the border with forest and mineral islands. This zone is affected by frequent fires characterized by abundance of charcoal in peat deposits and admixture of Carex globularis in the modern vegetation cover as an indicator of fire disturbance (Lamentowich, 2015). The peatland is still spreading via a paludification process covering the surrounding forested areas on mineral soils. These territories are characterized by abundance of tall, dry and dead conifer trunks with shallow peat deposits.

The average long-term peat accumulation rate is in range 0.03-0.048 $\mathrm{cm} \mathrm{yr}^{-1}$ (mean value is $\left.0.041 \pm 0.007 \mathrm{~cm} \mathrm{yr}^{-1}\right)$ dependent on the peat core depth, i.e. in the deepest cores a peat accumulation process is in 1.2-1.6 times faster over 10-11 kyr. The average peat accumulation rate based on 64 dates over different peat layers has higher value $0.067 \pm 0.018 \mathrm{~cm} \mathrm{yr}^{-1}\left(0.013-0.332 \mathrm{~cm} \mathrm{yr}^{-1}\right)$ mostly because of increased rates $\left(0.137-0.332 \mathrm{~cm} \mathrm{yr}^{-1}\right)$ of peat accumulation at the recent time (from 600 BP till now) for several cores.

High values of peat accumulation rate found for the bottom minerotrophic layers of Core 2 (0.086$0.277 \mathrm{~cm} \mathrm{yr}^{-1}$ ) which shifted till $0.049 \mathrm{~cm} \mathrm{yr}^{-1}$ about $9800 \mathrm{cal}$ years BP when vegetation changed from minerotrophic to the transition vegetation type. The highest values are found for the last $\sim 1200$

230 year for the cores 5-5 and 19a (0.332 and $0.336 \mathrm{~cm} \mathrm{yr}^{-1}$ correspondingly) which located on the Sphagnum fuscum ridges (water level $30-40 \mathrm{~cm}$ ) in the ridge-hollow complexes. For the same period increased values also found for the cores 18 and $27\left(0.137\right.$ and $0.147 \mathrm{~cm} \mathrm{yr}^{-1}$ correspondingly) with high water level (because of hydrophilic plants presence) and dominance of Sphagnum papilosum in moss layer. Generally the peat accumulation rate decreases for the period

235 6500-3000 cal years BP and increases for the older and younger dates reaching maximum values in the current time.

The oldest dates are found in the cores 2 and $18(\sim 11000$ and 10000 cal yr BP) that means a peat accumulation process started from the eastern and western peatland sides and occupied a central part during next 1500-2500 years. Thus, the lateral rate of peatland distribution might be assessed

240 between 0.65-1.0 $\mathrm{m} \mathrm{yr}^{-1}$ at the Preboreal and Boreal periods (11 700-8 $200 \mathrm{cal} \mathrm{yr} \mathrm{BP).}$

The oldest peat is 10989 cal yr BP, the oldest gyttja is 10053 cal yr BP. Peat growth started via terrestrialisation when the lake sediments filled the lake basin between 7000 and $6000 \mathrm{cal} \mathrm{yr}$ BP. The average age of peatland initiation based on 8 dates is 10265 cal yr BP (Appendix. Table A1).

\subsection{Bulk density and ash content}

Bulk density (BD) values increase linearly with depth from 0.016 till $0.348 \mathrm{~g} \mathrm{~cm}^{-1}$. Mostly it is caused by changes of peat stratigraphy: oligotrophic Sphagnum moss peat types have the lowest BD values because they consist only of the Sphagnum remains which mostly resistant to the decomposition processes and thus keep their initial volume (Pologova, Lapshina, 2001). For 
Mukhrino peatland many well-preserved Sphagnum fuscum peats (decomposition rate 5-10 \%) have been found on the depth below $200 \mathrm{~cm}$. Minerotrophic peat contains a lot of woody and sedge remains which over time lost volume structure and create dense peat layers, also it additionally may mix with mineral sediments at the bottom (Loisel, 2014).

Ash content changes irregular with the local maximum (5-8\%) at the $100 \mathrm{~cm}$ depth, with the next decline $(\sim 2.5 \%)$ and slow increase till the mineral bottom $(5-7 \%)$. These variations are related to the plant remain composition of peat - oligotrophic Sphagnum peat types have the lowest ash content while herbs and wood peat have increased concentration of ash (Loisel, 2014).

\subsection{Peat accumulation rate and carbon content}

LORCA ranges between 24.80-28.92 $\mathrm{g} \mathrm{C} \mathrm{m}^{-2} \mathrm{yr}^{-1}$ (average value is $26.93 \pm 1.76 \mathrm{~g} \mathrm{C} \mathrm{m}^{-2} \mathrm{yr}^{-1}$ ). The carbon accumulation rate was estimated also on a base of averaging data for each $10 \mathrm{~cm}$ layer. It has an average value $38.56 \pm 12.21 \mathrm{~g} \mathrm{C} \mathrm{m}^{-2} \mathrm{yr}^{-1}\left(28.46-57.91 \mathrm{~g} \mathrm{C} \mathrm{m}^{-2} \mathrm{yr}^{-1}\right)$. This value exceeds the LORCA because of irregularity of a carbon accumulation process.

The average $\mathrm{C}$ content for the $10 \mathrm{~cm}$ layer is $6.16 \pm 1.46 \mathrm{~kg} \mathrm{C} \mathrm{m}^{-2}$. The total amount of carbon stored in $4.3 \mathrm{~m}$ depth (average depth of all cores used for calculation) is $264.9 \pm 62.8 \mathrm{~kg} \mathrm{C} \mathrm{m}^{-2}$.

\subsection{POC \& DOC}

265 Relation between the DOC and POC dates is well-correlated $\left(\mathrm{r}^{2}=0.98\right.$, slope 0.93$)$ till the breaking point at $\sim 6000$ cal year BP (Fig. 2). Older dates are with the less slope (0.7) and more distributed $\left(r^{2}=0.75\right)$. Differences between DOC and POC ages from the same depth are linear ( $r^{2}$ equal 0.55 , slope is 0.14$)$ and range from $80 \mathrm{yr}$ at $50 \mathrm{~cm}$ untill $2000-3000 \mathrm{yr}$ at the bottom layers $(430-530 \mathrm{~cm})$. The linear (cores 5, 5-5, 18, 19, 27 and 31) and exponential (core 2) models have been used for calculations $\mathrm{d}_{\mathrm{doc} \_\mathrm{i}}$ (the depth POC came from). The average velocity of DOC downward movement is $0.047 \pm 0.019 \mathrm{~cm} \mathrm{yr}^{-1}$ (Fig. 2). The minimal $-0.52 \mathrm{~cm} \mathrm{yr}^{-1}$ and maximal $17.7 \mathrm{~cm} \mathrm{yr}^{-1}$ values are found for the upper $50 \mathrm{~cm}$ and probably related to the dating uncertainty of modern dates. Excluding those values the rest of calculated DOC movement rates are in range from -0.24 to $0.97 \mathrm{~cm} \mathrm{yr}^{-1}$. Negative values mean an upward DOC movement which found for 10 samples $(\sim 15 \%)$.

\section{Discussion}

The main physic-chemical peat properties such as carbon and ash contents, bulk density along the peat profile has been discovered in the current study. It is shown that $\sim 2 / 3$ of a peat body consists the sphagnum oligotrophic peat with low ash-content and low bulk density what nicely match to the existing data for the West Siberian lowland (Bleuten and Lapshina, 2001). These properties are 
mostly determined by composition of peat plant remains and climatic conditions of the time the peat had been formed and less related to the depth it had been extracted from (Chambers et al., 2010). The sphagnum peat bogs are dominant in the middle taiga zone (Peregon et al., 2008), presented mostly on the watersheds and cover $\sim 28 \%$ of whole zonal area (Terentieva, 2016). Generally, such peatlands have similar development history - initial waterlogging via paludification or terrestrialisation and forming the eutrophic peat layer, short term stage of mesotrophic peat and an abrupt change to the oligotrophic stage (Bolota Zapadnoi..., 2000; Bolotnie sistemy..., 2001).

High ash content values at the upper peatland layers $(50-100 \mathrm{~cm})$ has been found in all peat cores in this and other studies at the Mukhrino peatland (Lamentowicz et al., 2015; Tsyganov, et al., 2021). It might be explained by extremely high flooding 1-2 kiloyears ago with alluvial material sedimentation or by a probable fire occupied a peatland. But the fire history of Mukhrino FS over the last 1300 years have not discovered any significant amounts of charcoal (Lamentowicz et al., 2015).

The average peat accumulation rate $(A)$ is $0.067 \pm 0.02 \mathrm{~cm} \mathrm{yr}^{-1}$. The lowest average value $(0.04 \pm 0.02$

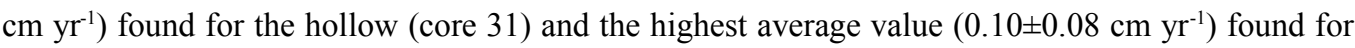
the ryam (core 2). The shape of the age-depth model was close to linear for the cores $19 \mathrm{a}$ and 31 , sshape for the cores 5a, 27 and 5-5, convex for the core 2 and broken for the core 18. Any features combining all cores into these groups have not been found. The majority of peat age-depth published models have concave shapes, meaning that a decay process is ongoing in the catotelm lower anaerobic peat layers $(\mathrm{Yu}, 2001)$. Absence of this shape model at the Mukhrino peatland may be caused by dominance of peat-moss (oligotrophic Sphagnum) remains (till $90 \%$ of core) which are the most resistant to decomposition (Thormann et al., 1999).

The A was the highest for oligotrophic peat $\left(0.080 \pm 0.038 \mathrm{~cm} \mathrm{yr}^{-1}\right)$, less for minerotrophic peat $\left(0.062 \pm 0.033 \mathrm{~cm} \mathrm{yr}^{-1}\right)$ and the lowest for transitional peat types $\left(0.061 \pm 0.027 \mathrm{~cm} \mathrm{yr}^{-1}\right)$. Oligotrophic peats mostly consist the remains of Sphagnum mosses, which are mostly resistant to the decomposition process. (Pologova and Lapshina, 2001) showed similar values for Great Vasyugan mire, where oligotrophic Sphagnum peat has higher A $\left(0.115 \mathrm{~cm} \mathrm{yr}^{-1}\right)$ then minerotrophic peat $\left(0.059 \mathrm{~cm} \mathrm{yr}^{-1}\right)$. Probably, these higher values explained by the location of Great Vasyugan mire in Southern taiga, the most favorable meteorological condition zone for peatlands development (Ivanov and Novikov, 1976), and the local plant biodiversity. In (Lapshina, 2011) the average A for

310 middle taiga zone is $0.056 \mathrm{~cm} \mathrm{yr}^{-1}$, when in Southern Taiga zone this value is $0.074-0.08 \mathrm{~cm} \mathrm{yr}^{-1}$, that supports the concept of the different external conditions of peat accumulation.

In case of eutrophic phase of peatland development, the peat accumulation process is determined by the mineral soil proximity and hence favorable geochemical conditions together with faster peat accumulation (Frolking et al., 2001) due to higher litter input (Thormann et al., 1999). Also the fen 
315 vegetation is less sensitive to climate conditions thus has more stable A (Frolking et al., 2001). Nonetheless, initial mass loss rate for fen plant species and older age, i.e. longer priod of decomposition, causes lower A value.

Altogether this means that the type of water supply (rain or ground water) and hence a way of nutrient income is one of the main limiting factors in peat accumulation process.

The average rate of carbon accumulation (CAR) is $37.99 \pm 11.4 \mathrm{gC} \mathrm{m}^{-2} \mathrm{yr}^{-1}$ (median value is $26.17 \mathrm{gC}$ $\left.\mathrm{m}^{-2} \mathrm{yr}^{-1}\right)$. This value inconsistency is caused by the skewed data to the high values mostly at the upper layers due to high $\mathrm{A}\left(0.15-0.33 \mathrm{~cm} \mathrm{yr}^{-1}\right)$ and at the bottom layers due to higher bulk density (0.4-1.4 $\left.\mathrm{g} \mathrm{cm}^{-3}\right)$. This value is similar to the average values for the middle boreal zone of Western Siberia (24.8 $\pm 5.5 \mathrm{gC} \mathrm{m}^{-2} \mathrm{yr}^{-1}$ ) (Lapshina and Pologova, 2011).

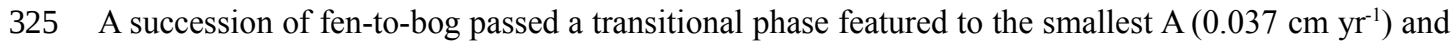
CAR (30.46 $\left.\mathrm{gC} \mathrm{m}^{-2} \mathrm{yr}^{-1}\right)$. Thus, reasons are probably related to the composition of peatland vegetation and its high decomposability caused by the lack of Sphanga contributing to the slow CAR (Bellen et al., 2011).

The highest CAR is found for the transitional and eutrophic peats, $76.0 \pm 65.9 \mathrm{gC} \mathrm{m}^{-2} \mathrm{yr}^{-1}$ and $63.1 \pm 48.0 \mathrm{gC} \mathrm{m}^{-2} \mathrm{yr}^{-1}$ correspondingly. The reason is abundance in peat the grass and woody debris, which are rich of carbon. Oligotrophic peat mostly consists the Sphagnum mosses remains which contains the lowest amount of carbon. Thus, the lowest value of CAR $\left(34.4 \pm 12.1 \mathrm{gC} \mathrm{m}^{-2} \mathrm{yr}^{-1}\right)$ found for oligotrophic peat.

Despite of the different view of the age-depth models all cumulative carbon accumulation curves have similar slightly positive exponential shape. It looks that A does not strongly affect CAR and does stay under control of other factors as vegetation remains diversity and its biochemical content, bulk density, carbon content and local topography and hydrology (Pologova and Lapshina, 2001; Pologova and Lapshina, 2002; Lapshina and Pologova, 2011).

Our results considered the hypothesis about DOC downward movement. Numerous studies have

340 analyzed DOC export from peatlands (Freeman et al., 2001; Frey and Smith, 2005; Buzek et. al., 2019; Blueten et al., 2020) but only few are related to the downward DOC movement and none covers this process in peatlands of Western Siberia, except (Schulze at al., 2015). In long-term processes as peatland development spanning last 10-12 kyr (Kremenetski et al., 2003) a DOC downward movement may be considered as an additional and significant path of global carbon cycle which must be taken into account for calculation of peatland carbon balance.

In our study we have estimated an average value of carbon downward movement as $0.047 \pm 0.019 \mathrm{~cm}$ $\mathrm{yr}^{-1}$. There is a slight tendency to decrease of these values (magnitude 2-10 times) forward to the mineral bottom, probably due to a low vertical hydraulic conductivity for the deep, dense and decomposed peats (Beckwith et al., 2003). Another possible reason is complete saturation of pore 
water by DOC which concentration systematically increases with depth and may prevent its further active penetration. Limited number of papers covers this topic (Chasar et al., 2000; Cole et al., 2002, Clymo and Bryant, 2008) and report concentrations $\sim 2 \mathrm{mmol} \mathrm{dm}^{-3}$ at the surface and 6-22 $\mathrm{mmol} \mathrm{dm} \mathrm{d}^{-3}$ at the bottom. There was not found any information for the West Siberian peatlands.

The negative values of DOC velocity mean an upward flux which might be caused by water table movement at the surface layers. A rising water table may catch a part of DOC produced in the lower layers and move it up to the surface thereby making converse between DOC and POC ages (Schulze et al., 2015). Several negative DOC velocities were found on the deeper layers $(200-300 \mathrm{~cm})$. This caused by the methodological flaw in the value calculations when the s-shape (cores 5a and 27) agedepth model is approximated by the linear regression.

There are few publications estimating DOC vertical velocity values. (Charman et al., 1999) used a vertical hydraulic conductivity equal to $31.5 \mathrm{~cm} \mathrm{yr}^{-1}$ to estimate DOC vertical transport in the UK. This value exceeds our results in $\sim 600$ times because based on a potential water movement which significantly ranges under conditions of saturation and peat physical properties (Chabson and Siegel, 1986). This value might be used as a potential rate of DOC downward movement but has to

365 be considered as a maximum possible velocity, i.e. a limiting factor.

The difference between DOC and POC ages in our study increases with depth (from 9 till $3044 \mathrm{yr}$, excluding three negative differences found for the upper $50 \mathrm{~cm}$ ) that supported only by the concept of DOC dowanward motion. Another reasons of date differences might be largely excluded:

- sedge and Scheuchzeria roots growing down the peat till the 2 meters (Glaser et al. 2012) have not been found in any dating sample (because of visual control of the peat samples for dating) and can not penetrate in the deeper layers. These remains would cause extreme inversions of the age-depth model (for example, when the modern roots reache the ancient peat layers) what not found in current study. The roots of trees and dwarf-shrubs occupy only the surface aerobic layer due to absence of aerenchyme cells;

375 - permafrost has not been distributed in the middle taiga zone last centuries and thus the cryoturbation can not cause so intensive and ubiquitous date discrepancy;

- periodical flooding of the Mukhrino peatland has to form an alluvium layer which, probably, has been detected once only in the upper layer;

- peatfires, which happens only in the extrimely hot and dry years in the taiga zone, do not explain behavior of the DOC and POC ages along a peat profile as well.

So, this process might be caused only by the continuous vertical flow of DOC over the thousands years while the POC stays on the same depth. Thus, the moving DOC penetrates deeper every year and the date discrepancy increases. 
This process is facilitated by the local relief position where Mukhrino peatland occupies the high second terrace and drained by the small rivers "Mukhrina" and "Bolshaya rechka" located 6-8 $\mathrm{m}$ lower from the eastern and western sides. This creates the piezometric gradient and allows the peatland water penetrates through the mineral bottom (clay layer with low hydraulic conductivity) and discharges to the streams (Fig. 3).

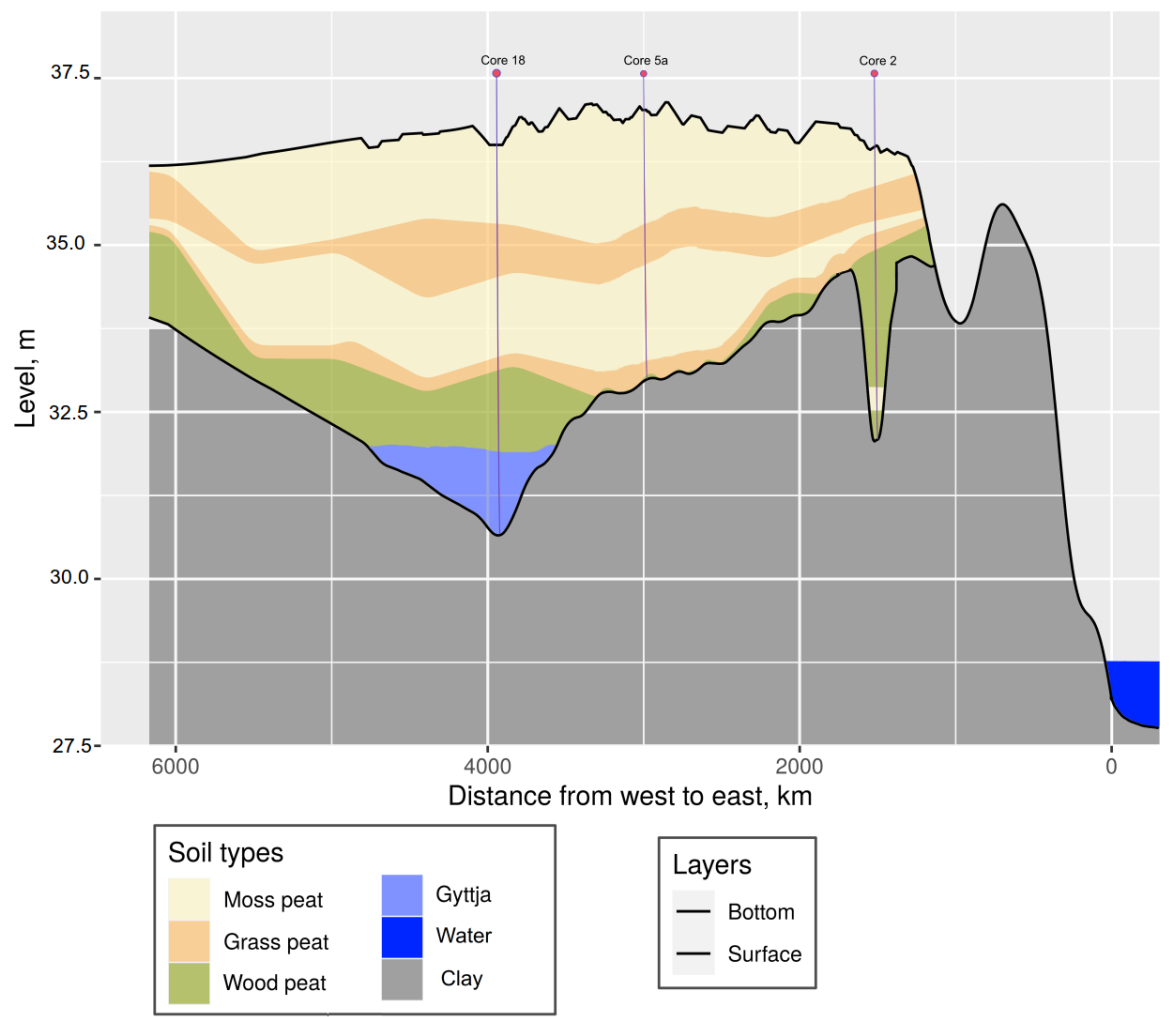

Figure 3: Peatland stratigraphy and shape of mineral bottom.

The mechanism of DOC downward movement is described in number of publications (Aravena et al., 1993; Charman et al., 1993, 1994, 1999; Chanton et al., 1995) showing that the gas ${ }^{14} \mathrm{C}$ ages are significantly younger in DOC than the particulate peat. The possible reason may be described by conversion of young DOC transported from the upper peat layers to $\mathrm{CO}_{2}$ and $\mathrm{CH}_{4}$ by microbial activity. In our previous study in Western Siberia the maximal age difference 6500 years has been recorded (Schulze et al., 2015). The results from Southwest England show that DOC is $830-1260 \mathrm{yr}$ younger than the peat it was extracted from (Charman et al., 1999). Clymo and Bryant (2008) has 
published perfect results about a $7 \mathrm{~m}$ deep peatland where differences between the peat and DOC ages increase with depth since 80 till $1835 \mathrm{yr}$.

In (Kraev et al., 2017) shown a possible way of methane displacement to the deeper soil horizons due to freezing of thick strata of epigenetic permafrost. The same mechanism potentially might be found for the peatlands, because high peat porosity is a favorable substrate for vertical water movement. The surface Mukhrino peatland layer freezes at the end of September - beginning of November. The water discharge completely stops at that time, thus a peatland becomes a huge reservoir filled by the high porosity substrate and water, which completely confined by ice pack from above. Frozen water may produce an extra pressure and pushes the labile dissolved form of carbon down.

Author Contributions: Conceptualization, E.L. and E.S.; methodology, E.S., I.K., E.Z.; software, E.Z.; investigation, E.Z., I.K.; writing - original draft preparation, E.Z., E.D.; writing - review and editing, E.S., I.K., E.D., E.Z.; visualization, E.Z.; supervision, E.S. and E.L.; All authors have read and agreed to the published version of the manuscript.

Acknowledgments: The research was carried out within the grant of the Tyumen region Government in accordance with the program of the West Siberian Interregional Scientific and Educational Centre (National Project "Nauka") and within the grant of the Yugra State University №17-02-07/66.

Conflicts of Interest: The authors declare no conflict of interest. The funders had no role in the design of the study; in the collection, analyses, or interpretation of data; in the writing of the manuscript, or in the decision to publish the results.

\section{References}

425 Aravena, R. and Wassenaar, L.I. Dissolved organic carbon and methane in a regional confined aquifer, southern Ontario, Canada: Carbon isotope evidence for associated subsurface sources. Applied Geochemistry, 8(5), 483-493. 1993. https://doi.org/10.1016/0883$\underline{\text { 2927(93)90077-T }}$

Baird, A.J., Belyea, L.R.B., Comas, X., Reeve, A.S., and Slater, L.D. Carbon cycling in northern peatlands. p. 299. 2013.

Beckwith, C.W., Baird, A.J., and Heathwaite, A.L. Anisotropy and depth related heterogeneity of hydraulic conductivity in a bog peat. I: Laboratory measurements. Hydrological processes, 17(1), 89-101. 2003. https://doi.org/10.1002/hyp.1116 
Beilman, D.W., MacDonald, G.M., Smith, L.C., and Reimer, P.J. Carbon accumulation in peatlands of West Siberia over the last 2000 years. Global Biogeochemical Cycles 23. (1), GB1012. 2009. https://doi.org/10.1029/2007GB003112

Billett, M.F., Garnett, M. H., and Harvey, F. UK peatland streams release old carbon dioxide to the atmosphere and young dissolved organic carbon to rivers. Geophysical Research Letters, 34(23), pp. 1-6. 2007. https://doi.org/10.1029/2007GL031797

Blaauw, M. 2020. clam: Classical Age-Depth Modelling of Cores from Deposits. R package https://cran.r-project.org/web/packages/clam/index.html (accessed on 05 ${ }^{\text {th }}$ August 2021)

Blaauw, M., Christen, J.A., and Aquino M.A. 2020. Rbacon: Age-depth modelling using Bayesian $\begin{array}{lllll}\text { statistics. } & \mathrm{R} & \text { package } & \text { version } & \text { htps:/cran.r- }\end{array}$ project.org/web/packages/rbacon/index.html (accessed on 05 ${ }^{\text {th }}$ August 2021)

445 Bleuten, W. and Lapshina, E.D. Carbon storage and atmospheric exchange by West Siberian peatlands. Physical Geography. Utrecht University, Utrecht-Tomsk. p. 116. 2001

Bleuten, W., Zarov, E., and Schmitz, O. A high-resolution transient 3-dimensional hydrological model of an extensive undisturbed bog complex in West Siberia. Mires and Peat, 26 (6). 2020. DOI: 10.19189/MaP.2019.OMB.StA.1769

Borren, W., Bleuten, W., and Lapshina, E.D. Holocene peat and carbon accumulation rates in the southern taiga of western Siberia. Quaternary Research 61, 42-51. 2004. https://doi.org/10.1016/j.yqres.2003.09.002

Buzek, F., Novak, M., Cejkova, B., Jackova, I., Curik, J., Veselovsky, F., Stpanova, M., Bohdalkova, L. Assessing DOC export from a Sphagnum dominated peatland using $\delta 13 \mathrm{C}$ and $\delta 18 \mathrm{O}$ H2O stable isotopes. Hydrological Processes, 33(21), 2792-2803. 2019. https://doi.org/10.1002/hyp.13528

Chambers, F., Beilman, D., Yu, Z. Methods for determining peat humification and for quantifying peat bulk density, organic matter and carbon content for palaeostudies of climate and peatland carbon dynamics. Mires and Peat. 7. 1-10. 2010.

Chanton, J. P., Bauer, J. E., Glaser, P. A., Siegel, D. I., Kelley, C. A., Tyler, S. C., ..., and Lazrus, A. 1995. Radiocarbon evidence for the substrates supporting methane formation within northern Minnesota peatlands. Geochimica et Cosmochimica Acta, 59(17), 3663-3668.

Charman, D.J., Aravena, R., and Warner, B.G. Carbon dynamics in a forested peatland in northeastern Ontario, Canada. Journal of Ecology, 55-62. 1994. https://doi.org/10.2307/2261385

Charman, D.J., Aravena, R., Bryant, C.L., and Harkness, D.D. Carbon isotopes in peat, DOC, CO2, and CH4 in a Holocene peatland on Dartmoor, Southwest England. Geology, 27(6), 539542. 1999. https://doi.org/10.1130/0091-7613(1999)027<0539:CIIPDC>2.3.CO;2 
Chasar, L.S., Chanton, J.P., Glaser, P.H., Siegel, D.I., and Rivers, J.S. Radiocarbon and stable carbon isotopic evidence for transport and transformation of dissolved organic carbon, dissolved inorganic carbon, and $\mathrm{CH} 4$ in a northern Minnesota peatland. Global Biogeochemical Cycles, 14(4), 1095-1108. 2000. https://doi.org/10.1029/1999GB001221

Chason, D.B. and Siegel, D.I. Hydraulic conductivity and related physical properties of peat, Lost River Peatland, northern Minnesota. Soil science, 142(2), 91-99. 1986.

Clymo, R.S. and Bryant, C.L. Diffusion and mass flow of dissolved carbon dioxide, methane, and dissolved organic carbon in a 7-m deep raised peat bog. Geochimica et Cosmochimica Acta, 72(8), 2048-2066. 2008. https://doi.org/10.1016/j.gca.2008.01.032

Cole, L., Bardgett, R.D., Ineson, P., and Adamson, J.K. Relationships between enchytraeid worms (Oligochaeta), climate change, and the release of dissolved organic carbon from blanket peat in northern England. Soil Biology and Biochemistry, 34(5), 599-607. 2002. https://doi.org/10.1016/S0038-0717(01)00216-4

Dyukarev, E., Filippova, N., Karpov, D., Shnyrev, N., Zarov, E., Filippov, I., Voropay N., Lapshina, E. Hydrometeorological dataset of West Siberian boreal peatland: a 10-year record from the Mukhrino Field Station. Earth System Science Data Discussions, 1-16. 2021. https://doi.org/10.5194/essd-13-2595-2021

Filippov, I.V. and Lapshina, E.D. Peatland unit types of lake-bog systems in the Middle Priob’ie (Western Siberia). In: Transactions of UNESCO Department of Yugorsky State University “Dynamics of Environment and Global Climate Change”. P. 115-124. 2008.

Freeman, C., Evans, C. D., Monteith, D. T., Reynolds, B., and Fenner, N. Export of organic carbon from peat soils. Nature, 412(6849), 785-785. 2001. https://doi.org/10.1038/35090628

Freeman, C, Fenner, N., Ostle, N. J. Kang, H. Dowrick, D. J. Reynolds, B., Lock, M. A. and Sleep, D. Hughes, S., and Hudson, J. 2004. Export of dissolved organic carbon from peatlands under elevated carbon dioxide levels. Nature, 430(6996), 195-198. https://doi.org/10.1038/nature02707

Frey, K.E. and Smith, L.C. Amplified carbon release from vast West Siberian peatlands by 2100. Geophysical Research Letters, 32(9), 1-4. 2005. https://doi.org/10.1029/2004GL022025

Frolking, S., Roulet, N.T., Moore, T.R., Richard, P.J., Lavoie, M., and Müller, S.D. Modeling northern peatland decomposition and peat accumulation. Ecosystems, 4(5), 479-498, 2001. https://doi.org/10.1007/s10021-001-0105-1

Glaser, P.H., Volin, J.H., Givnish, T J., Hansen, B.C.S., Stricker, C.A. Carbon and sediment accumulation in the Everglades (USA) during the past 4000 years: rates, drivers, and sources of error. Journal of Geophysical Research 117: G03026, 2012. https://doi.org/10.1029/2011JG001821 
Gvozdetskii, N.A., Krivolutskii, A.E., Makunina, A.A. Fiziko-geograficheskoe rajonirovanie Tyumenskoj oblasti [Physical and Geographical Zoning of the Tyumen Region]. Moscow State University Publishing House. P. 9-28. 1973. (in Russian).

Hua, Q., Barbetti, M., and Rakowski, Z. Atmospheric radiocarbon for the period 1950-2010. Radiocarbon 55, 2059-2072, 2013. https://doi.org/10.2458/azu js rc.v55i2.16177

Ivanov K. E. and Novikov S. M. (eds.) Bolota Zapadnoj Sibiri ih stroenie i gidrologicheskij rezhim [Peatlands of Western Siberia, their structure and hydrological regime]. 448 p. 1976.

Jaworski, T. and Niewiarowski, W. Frost peat mounds on Hermansenøya (O scar II L and, NW S valbard)-their genesis, age and terminology. Boreas, 41(4), 660-672, 2012. https://doi.org/10.1111/j.1502-3885.2012.00252.x

Kołaczek, P., Gałka, M., Lamentowicz, M., Marcisz, K., Kajukało-Drygalska, K., and KarpińskaKołaczek, M. Increased radiocarbon dating resolution of ombrotrophic peat profiles reveals periods of disturbance which were previously undetected. Quaternary Geochronology, 52, 21-28, 2019. https://doi.org/10.1016/j.quageo.2019.03.001

Kraev, G., Schulze, E.D., Yurova, A., Kholodov, A., Chuvilin, E., \& Rivkina, E. Cryogenic displacement and accumulation of biogenic methane in frozen soils. Atmosphere, 8(6), 105, 2017. https://doi.org/10.3390/atmos8060105

Kremenetski, K. V., Velichko, A. A., Borisova, O. K., MacDonald, G. M., Smith, L. C., Frey, K. E., and Orlova, L. A. Peatlands of the Western Siberian lowlands: current knowledge on zonation, carbon content and Late Quaternary history. Quaternary Science Reviews 22, 703-723, 2003. https://doi.org/10.1016/S0277-3791(02)00196-8

Lamentowicz, M., Słowiński, M., Marcisz, K., Zielińska, M., Kaliszan, K., Lapshina, E., Gilbert D., Buttler A., Fiałkiewicz-Kozieł B., Jassey V.E.J., Laggoun-Defarge, F., Kołaczek P. Hydrological dynamics and fire history of the last 1300 years in western Siberia reconstructed from a high-resolution, ombrotrophic peat archive. Quaternary Research, 84(3), 312-325, 2015. https://doi.org/10.1016/j.yqres.2015.09.002

Lapshina E.D. Peat grow dynamic on the bogs of taiga zone of West Siberia. In: Wset Siberian Peatlands and Carbon Cycle: Past and Present. Conference proceedings. p. 38-39, 2011.

Lapshina, E.D. and Pologova, N.N. Spatial dynamics of peat grows and carbon accumulation in sphagnum bogs (boreal West Siberia). In: West Siberian Peatlands and Carbon Cycle: past and present. Vomperskiy, S. E. (Ed.). Novosibirsk. p. 96-98, 2011.

Lapshina, E.D., Pologova, N.N., and Muldiyarov E.Ya. Pattern of development and carbon accumulation in homogenous Sphagnum fuscum-peat deposit on the south of West Siberia. In: Vasiliev, S., Titlyanova, A., and Velichko, A. (Eds.), West Siberian Peatlands and 
Carbon Cycle: past and present. Proceedings of International Field Symposium, Noyabrsk August 18-22, pp. 101-104, 2001.

Liss, O.L., Abramova, L.I., Avetov, N.A., Berezina, N.A., Inisheva, L.I., Kurnishkova, T.V., et al. Mire systems of Western Siberia and their nature conservation value (Bolotnye sistemy Zapadnoj Sibiri i ih prirodoohrannoe znachenie). 584 p., 2001. (in russian)

Loisel, J., Yu,Z., Beilman, D.W., Camill, P., Alm, J., Amesbury, M.J., Matthew, J., Anderson, S., Bochicchio, C., Barber, K., and Belyea, L.R. A database and synthesis of northern peatland soil properties and Holocene carbon and nitrogen accumulation. The Holocene 24, 10281042, 2014. https://doi.org/10.1177/0959683614538073

Peregon, A., Maksyutov, S., Kosykh, N.P., and Mironycheva-Tokareva, N. P. Mapbased inventory of wetland biomass and net primary production in Western Siberia. Journal of Geophysical Research: Biogeosciences, 1-12, 2008. https://doi.org/10.1029/2007JG000441

Pologova N.N. and Lapshina E.D. Nakoplenie ugleroda $\mathrm{v}$ torfyanyh zalezhah Bol'shogo Vasyuganskogo bolota [Carbon accumulation in peat deposits of the Great Vasyugan mire]. In: Bolshoe Vasyuganskoe boloto. Sovremennoe sostoyanie i processy razvitiya [Great Vasyugan Mire. Actual statement and development processes]. Tomsk. p. 174-179, 2002. (in Russian).

Pologova N.N., Lapshina E.D. Nakoplenie ugleroda v torfyanyh zalezhah Bol'shogo Vasyuganskogo bolota [Carbon accumulation in peat deposits of the Great Vasyugan mire]. In: IV Sobranie po klimatoekologicheskomu monitoringu [The fourth Climate-Ecological Monitoring Meeting], Tomsk. P. 72-73, 2001. (in Russian).

Reimer, P.J., Austin, W.E.N. Bard, E. Bayliss, A. Blackwell, P.G. Ramsey, C.B. Butzin, M. Cheng, H.H. Edwards, R.L., Friedrich M, et al. The IntCal20 Northern Hemisphere Radiocarbon Age Calibration Curve (0-55 cal kBP). Radiocarbon 62, 725-757, 2020. doi:10.1017/RDC.2020.41.

Schulze, E.D., Lapshina, E., Filippov, I., Kuhlmann, I., Mollicone, D. Carbon dynamics in boreal peatlands of the Yenisey region, Western Siberia. Biogeosciences, 12(23), 7057-7070, 2015. https://doi.org/10.5194/bg-12-7057-2015

Sheng, Y., Smith, L.C., MacDonald, G.M., Kremenetski, K.V., Frey, K.E., Velichko, A.A., Lee M., Beilman, D. and Dubinin, P. A high resolution GIS based inventory of the west Siberian peat carbon pool. Global Biogeochemical Cycles, 18(3), 1-14, 2004. https://doi.org/10.1029/2003GB002190

Smith, L.C., MacDonald, G.M., Velichko, A.A., Beilman, D.W., Borisova, O.K., Frey, K.E., Kremenetski, K.V., and Sheng, Y. Siberian peatlands a net carbon sink and global methane 
source since the early Holocene. Science, 303(5656), 353-356, 2004. DOI: 10.1126/science.1090553

Steinhof, A. Accelerator Mass Spectrometry of Radiocarbon. In: Schuur, E.A., Druffel, E.R., Trumbore, S.E. Radiocarbon and climate change. Switzerland: Springer International Publishing Switzerland. p. 253-278, 2016.

Steinhof, A., Altenburg, M., and Machts, H. Sample preparation at the Jena 14C laboratory. Radiocarbon, 59(3), 815-830, 2017. DOI: https://doi.org/10.1017/RDC.2017.50

Terentieva, I.E., Glagolev, M.V., Lapshina, E.D., Sabrekov, A.F., Maksyutov, S. Mapping of West Siberian taiga wetland complexes using Landsat imagery: implications for methane emissions. Biogeosciences, 13(16), 4615-4626, 2016. https://doi.org/10.5194/bg-13-4615$\underline{2016}$

Thormann, M.N., Szumigalski, A.R., and Bayley, S.E. Aboveground peat and carbon accumulation potentials along a bog-fen-marsh wetland gradient in southern boreal Alberta, Canada. Wetlands, 19(2), 305-317, 1999. https://doi.org/10.1007/BF03161761

585 Tsyganov, A.N., Zarov, E.A., Mazei, Y.A., Kulkov, M.G., Babeshko, K.V., Yushkovets, S.Y., Payne, R.J., Ratcliffe, J.L., Fatyunina, Yu.A., Zazovskaya, E.P., Lapshina, E.D. Key periods of peatland development and environmental changes in the middle taiga zone of Western Siberia during the Holocene. Ambio, 1-14, 2021. https://doi.org/10.1007/s13280-021$\underline{01545-7}$

590 Turetsky, M. R., Donahue, W., \& Benscoter, B. W. Experimental drying intensifies burning and carbon losses in a northern peatland. Nature Communications, 2(1), 1-5, 2011. doi: 10.1038/ncomms1523

Turunen, J., Tahvanainen, T., Tolonen, K., Pitkanen, A. Carbon accumulation in West Siberian mires, Russia. Global Biogeochemical Cycles 15, 285-296, 2001. https://doi.org/10.1029/2000GB001312

Väliranta, M., Oinonen, M., Seppä, H., Korkonen, S., Juutinen, S., Tuittila, E. S. Unexpected problems in AMS 14C dating of fen peat. Radiocarbon, 56(1), 95-108, 2014. https://doi.org/10.2458/56.16917

Van Bellen, S., Garneau, M., Booth, R. K. Holocene carbon accumulation rates from three ombrotrophic peatlands in boreal Quebec, Canada: impact of climate-driven ecohydrological change. The Holocene, 21(8), 1217-1231, 2011. https://doi.org/10.1177/0959683611405243

Xu, J., Morris, P.J., Liu, J., Holden, J. PEATMAP: Refining estimates of global peatland distribution based on a meta-analysis. Catena 160, 134-140, 2018. https://doi.org/10.1016/j.catena.2017.09.010 
https://doi.org/10.5194/bg-2021-211

Preprint. Discussion started: 17 August 2021

(C) Author(s) 2021. CC BY 4.0 License.

Yu, Z., Campbell, I.D., Vitt, D.H., Apps, M.J. Modelling long-term peatland dynamics. I. Concepts, review, and proposed design. Ecological Modelling, 145(2-3), 197-210, 2001. https://doi.org/10.1016/S0304-3800(01)00391-X

Yu, Z., Charman, D., Beilman, D.W., Brovkin, V., Large, D. J. Carbon in Peat on Earth through time 610 (C-PEAt). Past Global Changes Magazine 22, 92, 2014.

Zemtsov, A.A., Mezentsev, A.V., Inisheva, L.I. Mires of Western Siberia: their role in the biosphere (Bolota Zapadnoj Sibiri: ih rol' v biosfere). 72 p, 1998. (in russian)

615 
https://doi.org/10.5194/bg-2021-211

Preprint. Discussion started: 17 August 2021

(c) Author(s) 2021. CC BY 4.0 License.

Appendix

620 Table A1. Radiocarbon dates of the peat core from the Mukhrino peatland.

\begin{tabular}{|c|c|c|c|c|c|c|c|c|c|c|}
\hline $\begin{array}{c}\text { Lab } \\
\text { number }\end{array}$ & Plot & $\begin{array}{l}\text { Depth, } \\
\text { cm }\end{array}$ & Fraction & $\begin{array}{c}\Delta 14 \mathrm{C} \\
(\%)\end{array}$ & err (\%o) & $\begin{array}{c}\text { PMC } \\
{[\%]}\end{array}$ & $\begin{array}{c}\text { err PMC } \\
{[\%]}\end{array}$ & C14 BP & $\begin{array}{c}\text { Calibrated age } \\
\text { BP }(95 \% \\
\text { confidence } \\
\text { interval })\end{array}$ & $\begin{array}{l}\text { Calibrated } \\
\text { age BP error }\end{array}$ \\
\hline 18831 & Plot18 & 49 & $<1,6 \mu \mathrm{m}$ & 148.4 & 1.7 & 115.79 & 0.17 & $-1177,7$ & -24.79 & 11,8 \\
\hline 18830 & Plot18 & 49 & $<36>1,6 \mu \mathrm{m}$ & 107.1 & 1.8 & 111.62 & 0.18 & $-883,1$ & -27.325 & 12,9 \\
\hline 18822 & Plot18 & 146 & $<36>1,6 \mu \mathrm{m}$ & -138.2 & 1.4 & 86.89 & 0.14 & 1128,9 & 1018,0 & 12,9 \\
\hline 18823 & Plot18 & 146 & $<1,6 \mu \mathrm{m}$ & -139 & 1.9 & 86.81 & 0.19 & 1136,3 & 1067.5 & 17,6 \\
\hline 18824 & Plot18 & 196 & $<36>1,6 \mu \mathrm{m}$ & -304.3 & 1.2 & 70.14 & 0.12 & 2849,1 & 2965.5 & 13,7 \\
\hline 18825 & Plot18 & 196 & $<1,6 \mu \mathrm{m}$ & -279.9 & 1.3 & 72.6 & 0.13 & 2572,2 & 2732.5 & 14,4 \\
\hline 18999 & Plot18 & 275 & $<36>1,6 \mu \mathrm{m}$ & -334.5 & 1.1 & 67.1 & 0.11 & 3205,1 & 3419.5 & 13,2 \\
\hline 19000 & Plot18 & 275 & $<1,6 \mu \mathrm{m}$ & -311 & 1.2 & 69.46 & 0.12 & 2927,4 & 3079,0 & 13,9 \\
\hline 19001 & Plot18 & 296 & $<36>1,6 \mu \mathrm{m}$ & -428.2 & 1 & 57.66 & 0.1 & 4423,0 & 5046.5 & 13,9 \\
\hline 19002 & Plot18 & 296 & $<1,6 \mu \mathrm{m}$ & -416 & 1.1 & 58.88 & 0.11 & 4254,8 & 4841,0 & 15,0 \\
\hline 18826 & Plot18 & 346 & $<36>1,6 \mu \mathrm{m}$ & -466.2 & 1.2 & 53.82 & 0.12 & 4976,6 & 5674,0 & 17,9 \\
\hline 18827 & Plot18 & 346 & $<1,6 \mu \mathrm{m}$ & -436.6 & 1.4 & 56.81 & 0.14 & 4542,3 & 5184,0 & 19,8 \\
\hline 19004 & Plot18 & 396 & $<1,6 \mu \mathrm{m}$ & -484.2 & 1 & 52 & 0.1 & 5253,0 & 6053,0 & 15,4 \\
\hline 19003 & Plot18 & 396 & $<36>1,6 \mu \mathrm{m}$ & -544 & 0.9 & 45.97 & 0.09 & 6243,1 & 7140.5 & 15,7 \\
\hline 18821 & Plot18 & 446 & $<1,6 \mu \mathrm{m}$ & -618 & 0.9 & 38.52 & 0.09 & 7663,4 & 8458,0 & 18,7 \\
\hline 18820 & Plot18 & 446 & $<36>1,6 \mu \mathrm{m}$ & -662 & 0.8 & 34.08 & 0.08 & 8647,2 & 9609,0 & 18,8 \\
\hline 18828 & Plot18 & 479 & $<36>1,6 \mu \mathrm{m}$ & -673.7 & 0.8 & 32.9 & 0.08 & 8930,3 & 10052.5 & 19,5 \\
\hline 18829 & Plot18 & 479 & $<1,6 \mu \mathrm{m}$ & -621.9 & 1.1 & 38.12 & 0.11 & 7747,3 & 8520,0 & 23,1 \\
\hline 18894 & Plot19a & 46 & $<36>1,6 \mu \mathrm{m}$ & -152.9 & 1.5 & 85.4 & 0.15 & 1267,8 & 1224.5 & 14,1 \\
\hline 18895 & Plot19a & 46 & $<1,6 \mu \mathrm{m}$ & -124.5 & 1.6 & 88.27 & 0.16 & 1002,3 & 894.5 & 14,5 \\
\hline 18896 & Plot19a & 96 & $<36>1,6 \mu \mathrm{m}$ & -272 & 1.4 & 73.4 & 0.14 & 2484,2 & 2601,0 & 15,3 \\
\hline 18897 & Plot19a & 96 & $<1,6 \mu \mathrm{m}$ & -241.9 & 1.5 & 76.44 & 0.15 & 2158,2 & 2180,0 & 15,7 \\
\hline 18898 & Plot19a & 146 & $<36>1,6 \mu \mathrm{m}$ & -353 & 1.2 & 65.23 & 0.12 & 3432,1 & 3706.5 & 14,8 \\
\hline 18899 & Plot19a & 146 & $<1,6 \mu \mathrm{m}$ & -322.3 & 1.4 & 68.33 & 0.14 & 3059,1 & 3279.5 & 16,4 \\
\hline 18901 & Plot19a & 196 & $<1,6 \mu \mathrm{m}$ & -427.9 & 1.3 & 57.68 & 0.13 & 4420,2 & 5053,0 & 18,1 \\
\hline 18900 & Plot19a & 196 & $<36>1,6 \mu \mathrm{m}$ & -459.3 & 1.3 & 54.51 & 0.13 & 4874,3 & 5617.5 & 19,1 \\
\hline 18903 & Plot19a & 246 & $<1,6 \mu \mathrm{m}$ & -500.4 & 1.1 & 50.38 & 0.11 & 5507,2 & 6334,0 & 17,5 \\
\hline 18902 & Plot19a & 246 & $<36>1,6 \mu \mathrm{m}$ & -525.6 & 1.1 & 47.83 & 0.11 & 5924,5 & 6732,0 & 18,5 \\
\hline 18905 & Plot19a & 296 & $<1,6 \mu \mathrm{m}$ & -556.6 & 1 & 44.7 & 0.1 & 6468,1 & 7377,0 & 18,0 \\
\hline 18904 & Plot19a & 296 & $<36>1,6 \mu \mathrm{m}$ & -611.8 & 1 & 39.14 & 0.1 & 7535,2 & 8309.5 & 20,5 \\
\hline 18907 & Plot19a & 346 & $<1,6 \mu \mathrm{m}$ & -601.8 & 1 & 40.15 & 0.1 & 7330,5 & 8108.5 & 20,0 \\
\hline 18906 & Plot19a & 346 & $<36>1,6 \mu \mathrm{m}$ & -663 & 1 & 33.98 & 0.1 & 8670,8 & 9613.5 & 23,6 \\
\hline 18909 & Plot19a & 396 & $<1,6 \mu \mathrm{m}$ & -476.3 & 1.2 & 52.8 & 0.12 & 5130,3 & 5845.5 & 18,2 \\
\hline 18908 & Plot19a & 396 & $<36>1,6 \mu \mathrm{m}$ & -634.2 & 1 & 36.88 & 0.1 & 8012,9 & 8889,0 & 21,8 \\
\hline 18911 & Plot19a & 430 & $<1,6 \mu \mathrm{m}$ & -597.8 & 1 & 40.56 & 0.1 & 7248,9 & 8076.5 & 19,8 \\
\hline 18910 & Plot19a & 430 & $<36>1,6 \mu \mathrm{m}$ & -685.5 & 0.9 & 31.71 & 0.09 & 9226,2 & 10386.5 & 22,8 \\
\hline 18815 & Plot2 & 46 & $<1,6 \mu \mathrm{m}$ & 24.6 & 1.6 & 103.31 & 0.16 & $-261,6$ & -6.5 & 12,4 \\
\hline 18814 & Plot2 & 46 & $<36>1,6 \mu \mathrm{m}$ & 61.5 & 1.8 & 107.03 & 0.18 & $-545,8$ & -33.185 & 13,5 \\
\hline 18801 & Plot2 & 96 & $<1,6 \mu \mathrm{m}$ & -217.4 & 1.2 & 78.91 & 0.12 & 1902,7 & 1805,0 & 12,2 \\
\hline 18800 & Plot2 & 96 & $<36>1,6 \mu \mathrm{m}$ & -232.7 & 1.3 & 77.36 & 0.13 & 2062,1 & 2022,0 & 13,5 \\
\hline 18796 & Plot2 & 146 & $<36>1,6 \mu \mathrm{m}$ & -475.1 & 1.1 & 52.93 & 0.11 & 5110,6 & 5837,0 & 16,7 \\
\hline 18797 & Plot2 & 146 & $<1,6 \mu \mathrm{m}$ & -437.9 & 1.2 & 56.67 & 0.12 & 4562,1 & 5195,0 & 17,0 \\
\hline 18809 & Plot2 & 196 & $<1,6 \mu \mathrm{m}$ & -496.7 & 1 & 50.75 & 0.1 & 5448,5 & 6249.5 & 15,8 \\
\hline 18808 & Plot2 & 196 & $<36>1,6 \mu \mathrm{m}$ & -549.4 & 1 & 45.43 & 0.1 & 6338,0 & 7242,0 & 17,7 \\
\hline 18803 & Plot2 & 246 & $<1,6 \mu \mathrm{m}$ & -560.7 & 0.9 & 44.29 & 0.09 & 6542,2 & 7459.5 & 16,3 \\
\hline
\end{tabular}


https://doi.org/10.5194/bg-2021-211

Preprint. Discussion started: 17 August 2021

(c) Author(s) 2021. CC BY 4.0 License.

\begin{tabular}{|c|c|c|c|c|c|c|c|c|c|c|}
\hline 18802 & Plot2 & 246 & $<36>1,6 \mu \mathrm{m}$ & -591.4 & 0.9 & 41.2 & 0.09 & 7123,1 & 7940,0 & 17,5 \\
\hline 18798 & Plot2 & 296 & $<36>1,6 \mu \mathrm{m}$ & -629 & 0.8 & 37.4 & 0.08 & 7900,5 & 8763.5 & 17,2 \\
\hline 18799 & Plot2 & 296 & $<1,6 \mu \mathrm{m}$ & -597.5 & 0.9 & 40.58 & 0.09 & 7244,9 & 8073.5 & 17,8 \\
\hline 18810 & Plot2 & 346 & $<36>1,6 \mu \mathrm{m}$ & -667.9 & 0.7 & 33.49 & 0.07 & 8787,5 & 9797,0 & 16,8 \\
\hline 18811 & Plot2 & 346 & $<1,6 \mu \mathrm{m}$ & -637 & 1 & 36.6 & 0.1 & 8074,1 & 8938,0 & 21,9 \\
\hline 18817 & Plot2 & 396 & $<1,6 \mu \mathrm{m}$ & -638.6 & 1 & 36.44 & 0.1 & 8109,3 & 9058.5 & 22,0 \\
\hline 18816 & Plot2 & 396 & $<36>1,6 \mu \mathrm{m}$ & -674.9 & 1.7 & 32.78 & 0.17 & 8959,6 & 10070.5 & 41,6 \\
\hline 18813 & Plot2 & 446 & $<1,6 \mu \mathrm{m}$ & -658.6 & 0.8 & 34.42 & 0.08 & 8567,5 & 9521.5 & 18,6 \\
\hline 18812 & Plot2 & 446 & $<36>1,6 \mu \mathrm{m}$ & -692.7 & 0.8 & 30.98 & 0.08 & 9413,3 & 10640,0 & 20,7 \\
\hline 18807 & Plot2 & 496 & $<1,6 \mu \mathrm{m}$ & -660.1 & 0.8 & 34.27 & 0.08 & 8602,5 & 9563.5 & 18,7 \\
\hline 18806 & Plot2 & 496 & $<36>1,6 \mu \mathrm{m}$ & -695.7 & 0.8 & 30.68 & 0.08 & 9491,5 & 10833,0 & 20,9 \\
\hline 18805 & Plot2 & 523 & $<1,6 \mu \mathrm{m}$ & -606.8 & 0.8 & 39.64 & 0.08 & 7433,2 & 8257.5 & 16,2 \\
\hline 18804 & Plot2 & 523 & $<36>1,6 \mu \mathrm{m}$ & -680.9 & 0.9 & 32.17 & 0.09 & 9110,5 & 10289.5 & 22,4 \\
\hline 18818 & Plot2 & 524 & $<36>1,6 \mu \mathrm{m}$ & -701.1 & 0.8 & 30.13 & 0.08 & 9636,8 & 10989,0 & 21,3 \\
\hline 18819 & Plot2 & 524 & $<1,6 \mu \mathrm{m}$ & -630.1 & 1 & 37.3 & 0.1 & 7922,0 & 8791.5 & 21,5 \\
\hline 18873 & Plot27 & 46 & $<1,6 \mu \mathrm{m}$ & 38.6 & 1.6 & 104.72 & 0.16 & $-370,5$ & -33.09 & 12,3 \\
\hline 18872 & Plot27 & 46 & $<36>1,6 \mu \mathrm{m}$ & 16.3 & 1.8 & 102.47 & 0.18 & $-196,0$ & -6.105 & 14,1 \\
\hline 18874 & Plot27 & 90 & $<36>1,6 \mu \mathrm{m}$ & -86.6 & 1.5 & 92.1 & 0.15 & 661,1 & 614,0 & 13,1 \\
\hline 18875 & Plot27 & 90 & $<1,6 \mu \mathrm{m}$ & -83.8 & 1.6 & 92.38 & 0.16 & 636,7 & 605,0 & 13,9 \\
\hline 18876 & Plot27 & 140 & $<36>1,6 \mu \mathrm{m}$ & -197.9 & 1.3 & 80.88 & 0.13 & 1704,6 & 1617,0 & 12,9 \\
\hline 18877 & Plot27 & 140 & $<1,6 \mu \mathrm{m}$ & -180.6 & 1.4 & 82.62 & 0.14 & 1533,6 & 1413.5 & 13,6 \\
\hline 18879 & Plot27 & 196 & $<1,6 \mu \mathrm{m}$ & -359.6 & 1.2 & 64.57 & 0.12 & 3513,8 & 3772,0 & 14,9 \\
\hline 18878 & Plot27 & 196 & $<36>1,6 \mu \mathrm{m}$ & -370.6 & 1.2 & 63.46 & 0.12 & 3653,1 & 3990.5 & 15,2 \\
\hline 18880 & Plot27 & 246 & $<36>1,6 \mu \mathrm{m}$ & -503.2 & 1 & 50.09 & 0.1 & 5553,6 & 6346,0 & 16,0 \\
\hline 18881 & Plot27 & 246 & $<1,6 \mu \mathrm{m}$ & -468.5 & 1.1 & 53.59 & 0.11 & 5011,0 & 5772,0 & 16,5 \\
\hline 18883 & Plot27 & 296 & $<1,6 \mu \mathrm{m}$ & -547.4 & 1.2 & 45.64 & 0.12 & 6301,0 & 7214.5 & 21,1 \\
\hline 18882 & Plot27 & 296 & $<36>1,6 \mu \mathrm{m}$ & -594.3 & 1.1 & 40.91 & 0.11 & 7179,9 & 7983.5 & 21,6 \\
\hline 18885 & Plot27 & 346 & $<1,6 \mu \mathrm{m}$ & -592.8 & 1 & 41.06 & 0.1 & 7150,5 & 7975,0 & 19,5 \\
\hline 18884 & Plot27 & 346 & $<36>1,6 \mu \mathrm{m}$ & -634.3 & 1 & 36.87 & 0.1 & 8015,1 & 8889.5 & 21,8 \\
\hline 18887 & Plot27 & 396 & $<1,6 \mu \mathrm{m}$ & -631.6 & 0.9 & 37.14 & 0.09 & 7956,5 & 8817,0 & 19,4 \\
\hline 18886 & Plot27 & 396 & $<36>1,6 \mu \mathrm{m}$ & -676.6 & 1 & 32.6 & 0.1 & 9003,9 & 10199,0 & 24,6 \\
\hline 18888 & Plot27 & 405 & $<36>1,6 \mu \mathrm{m}$ & -665.6 & 0.8 & 33.72 & 0.08 & 8732,5 & 9718.5 & 19,0 \\
\hline 18889 & Plot27 & 405 & $<1,6 \mu \mathrm{m}$ & -626.3 & 1 & 37.68 & 0.1 & 7840,5 & 8620,0 & 21,3 \\
\hline 18891 & Plot27 & 412 & $<1,6 \mu \mathrm{m}$ & -587.6 & 0.9 & 41.58 & 0.09 & 7049,4 & 7869,0 & 17,4 \\
\hline 18890 & Plot27 & 412 & $<36>1,6 \mu \mathrm{m}$ & -659.3 & 0.8 & 34.35 & 0.08 & 8583,8 & 9540,0 & 18,7 \\
\hline 18854 & Plot31 & 46 & $<36>1,6 \mu \mathrm{m}$ & -96.2 & 1.4 & 91.13 & 0.14 & 746,1 & 676,0 & 12,3 \\
\hline 18855 & Plot31 & 46 & $<1,6 \mu \mathrm{m}$ & -80.8 & 1.5 & 92.68 & 0.15 & 610,6 & 599.5 & 13,0 \\
\hline 18857 & Plot31 & 96 & $<1,6 \mu \mathrm{m}$ & -193.7 & 1.4 & 81.3 & 0.14 & 1663,0 & 1605,0 & 13,8 \\
\hline 18856 & Plot31 & 96 & $<36>1,6 \mu \mathrm{m}$ & -208 & 1.4 & 79.86 & 0.14 & 1806,6 & 1684.5 & 14,1 \\
\hline 18858 & Plot31 & 146 & $<36>1,6 \mu \mathrm{m}$ & -299.3 & 1.3 & 70.64 & 0.13 & 2792,1 & 2901.5 & 14,8 \\
\hline 18859 & Plot31 & 146 & $<1,6 \mu \mathrm{m}$ & -291.2 & 1.6 & 71.47 & 0.16 & 2698,2 & 2803,0 & 18,0 \\
\hline 18861 & Plot31 & 196 & $<1,6 \mu \mathrm{m}$ & -408.6 & 1.1 & 59.63 & 0.11 & 4153,2 & 4702,0 & 14,8 \\
\hline 18860 & Plot31 & 196 & $<36>1,6 \mu \mathrm{m}$ & -428.6 & 1.2 & 57.61 & 0.12 & 4430,0 & 5072.5 & 16,7 \\
\hline 18863 & Plot31 & 246 & $<1,6 \mu \mathrm{m}$ & -494.6 & 1.1 & 50.95 & 0.11 & 5416,9 & 6240,0 & 17,3 \\
\hline 18862 & Plot31 & 246 & $<36>1,6 \mu \mathrm{m}$ & -510.4 & 1.1 & 49.37 & 0.11 & 5669,9 & 6446.5 & 17,9 \\
\hline 18865 & Plot31 & 296 & $<1,6 \mu \mathrm{m}$ & -558.9 & 1.1 & 44.47 & 0.11 & 6509,6 & 7403,0 & 19,8 \\
\hline 18864 & Plot31 & 296 & $<36>1,6 \mu \mathrm{m}$ & -620.6 & 1 & 38.26 & 0.1 & 7717,8 & 8484,0 & 21,0 \\
\hline 18867 & Plot31 & 346 & $<1,6 \mu \mathrm{m}$ & -610.4 & 0.9 & 39.28 & 0.09 & 7506,5 & 8296.5 & 18,4 \\
\hline 18866 & Plot31 & 346 & $<36>1,6 \mu \mathrm{m}$ & -667.4 & 0.9 & 33.54 & 0.09 & 8775,5 & 9789.5 & 21,5 \\
\hline 18869 & Plot31 & 363 & $<1,6 \mu \mathrm{m}$ & -617 & 0.9 & 38.62 & 0.09 & 7642,6 & 8448.5 & 18,7 \\
\hline 18868 & Plot31 & 363 & $<36>1,6 \mu \mathrm{m}$ & -674.4 & 0.8 & 32.83 & 0.08 & 8947,4 & 10059.5 & 19,6 \\
\hline 18871 & Plot31 & 376 & $<1,6 \mu \mathrm{m}$ & -639.2 & 1 & 36.38 & 0.1 & 8122,6 & 9062,0 & 22,1 \\
\hline 18870 & Plot31 & 376 & $<36>1,6 \mu \mathrm{m}$ & -691 & 0.9 & 31.16 & 0.09 & 9366,8 & 10591.5 & 23,2 \\
\hline 19006 & Plot5_5 & 46 & $<1,6 \mu \mathrm{m}$ & 3.6 & 1.3 & 101.18 & 0.13 & $-94,2$ & -5.82 & 10,3 \\
\hline
\end{tabular}


https://doi.org/10.5194/bg-2021-211

Preprint. Discussion started: 17 August 2021

(c) Author(s) 2021. CC BY 4.0 License.

\begin{tabular}{|c|c|c|c|c|c|c|c|c|c|c|}
\hline 19005 & Plot5_5 & 46 & $<36>1,6 \mu \mathrm{m}$ & -20.7 & 1.4 & 98.73 & 0.14 & 102,7 & 144.5 & 11,4 \\
\hline 19008 & Plot5_5 & 96 & $<1,6 \mu \mathrm{m}$ & -123.4 & 1.2 & 88.39 & 0.12 & 991,4 & 879,0 & 10,9 \\
\hline 19007 & Plot5_5 & 96 & $<36>1,6 \mu \mathrm{m}$ & -147.2 & 1.3 & 85.99 & 0.13 & 1212,5 & 1123.5 & 12,1 \\
\hline 19010 & Plot5_5 & 146 & $<1,6 \mu \mathrm{m}$ & -274 & 1.1 & 73.2 & 0.11 & 2506,1 & 2608.5 & 12,1 \\
\hline 19009 & Plot5_5 & 146 & $<36>1,6 \mu \mathrm{m}$ & -300 & 1.1 & 70.58 & 0.11 & 2798,9 & 2904.5 & 12,5 \\
\hline 19012 & Plot5_5 & 196 & $<1,6 \mu \mathrm{m}$ & -429.5 & 1 & 57.52 & 0.1 & 4442,6 & 5119,0 & 14,0 \\
\hline 19011 & Plot5_5 & 196 & $<36>1,6 \mu \mathrm{m}$ & -468.6 & 1 & 53.58 & 0.1 & 5012,5 & 5772.5 & 15,0 \\
\hline 19013 & Plot5_5 & 246 & $<36>1,6 \mu \mathrm{m}$ & -597 & 0.8 & 40.63 & 0.08 & 7235,0 & 8070,0 & 15,8 \\
\hline 19014 & Plot5_5 & 246 & $<1,6 \mu \mathrm{m}$ & -552.2 & 0.9 & 45.15 & 0.09 & 6387,7 & 7339.5 & 16,0 \\
\hline 19015 & Plot5_5 & 296 & $<36>1,6 \mu \mathrm{m}$ & -642.1 & 0.9 & 36.09 & 0.09 & 8186,9 & 9145,0 & 20,0 \\
\hline 19016 & Plot5_5 & 296 & $<1,6 \mu \mathrm{m}$ & -579.9 & 1.1 & 42.36 & 0.11 & 6900,1 & 7729.5 & 20,8 \\
\hline 18850 & Plot5_5 & 313 & $<36>1,6 \mu \mathrm{m}$ & -680.4 & 0.8 & 32.22 & 0.08 & 9098,0 & 10243.5 & 19,9 \\
\hline 18851 & Plot5_5 & 313 & $<1,6 \mu \mathrm{m}$ & -600.9 & 1 & 40.24 & 0.1 & 7312,5 & 8105,0 & 19,9 \\
\hline 18853 & Plot5_5 & 314 & $<1,6 \mu \mathrm{m}$ & -583.3 & 1 & 42.01 & 0.1 & 6966,7 & 7809.5 & 19,1 \\
\hline 18852 & Plot5_5 & 314 & $<36>1,6 \mu \mathrm{m}$ & -680.5 & 0.8 & 32.21 & 0.08 & 9100,5 & 10247.5 & 19,9 \\
\hline 18915 & Plot5a & 46 & $<1,6 \mu \mathrm{m}$ & -158.2 & 1.5 & 84.88 & 0.15 & 1316,9 & 1234,0 & 14,2 \\
\hline 18914 & Plot5a & 46 & $<36>1,6 \mu \mathrm{m}$ & -183.4 & 1.7 & 82.34 & 0.17 & 1560,9 & 1451,0 & 16,6 \\
\hline 18917 & Plot5a & 96 & $<1,6 \mu \mathrm{m}$ & -240 & 1.5 & 76.63 & 0.15 & 2138,2 & 2149.5 & 15,7 \\
\hline 18916 & Plot5a & 96 & $<36>1,6 \mu \mathrm{m}$ & -243.9 & 1.5 & 76.24 & 0.15 & 2179,2 & 2211,0 & 15,8 \\
\hline 18919 & Plot5a & 146 & $<1,6 \mu \mathrm{m}$ & -356.3 & 1.4 & 64.9 & 0.14 & 3472,8 & 3738.5 & 17,3 \\
\hline 18918 & Plot5a & 146 & $<36>1,6 \mu \mathrm{m}$ & -376.5 & 1.4 & 62.87 & 0.14 & 3728,1 & 4068,0 & 17,9 \\
\hline 18921 & Plot5a & 196 & $<1,6 \mu \mathrm{m}$ & -465.5 & 1.1 & 53.89 & 0.11 & 4966,2 & 5669,0 & 16,4 \\
\hline 18920 & Plot5a & 196 & $<36>1,6 \mu \mathrm{m}$ & -473.8 & 1.1 & 53.06 & 0.11 & 5090,9 & 5830,0 & 16,6 \\
\hline 18922 & Plot5a & 246 & $<36>1,6 \mu \mathrm{m}$ & -544.2 & 0.9 & 45.96 & 0.09 & 6244,8 & 7141.5 & 15,7 \\
\hline 18923 & Plot5a & 246 & $<1,6 \mu \mathrm{m}$ & -511 & 1 & 49.31 & 0.1 & 5679,7 & 6449,0 & 16,3 \\
\hline 18925 & Plot5a & 296 & $<1,6 \mu \mathrm{m}$ & -569.2 & 0.9 & 43.43 & 0.09 & 6699,7 & 7560,0 & 16,6 \\
\hline 18924 & Plot5a & 296 & $<36>1,6 \mu \mathrm{m}$ & -592.6 & 0.9 & 41.07 & 0.09 & 7148,5 & 7974.5 & 17,6 \\
\hline 18927 & Plot5a & 346 & $<1,6 \mu \mathrm{m}$ & -519.4 & 1 & 48.45 & 0.1 & 5821,0 & 6639.5 & 16,6 \\
\hline 18926 & Plot5a & 346 & $<36>1,6 \mu \mathrm{m}$ & -623 & 0.8 & 38.01 & 0.08 & 7770,5 & 8529,0 & 16,9 \\
\hline 18929 & Plot5a & 396 & $<1,6 \mu \mathrm{m}$ & -606.4 & 0.8 & 39.69 & 0.08 & 7423,1 & 8254,0 & 16,2 \\
\hline 18928 & Plot5a & 396 & $<36>1,6 \mu \mathrm{m}$ & -645.7 & 0.9 & 35.73 & 0.09 & 8267,4 & 9268.5 & 20,2 \\
\hline 18931 & Plot5a & 405 & $<1,6 \mu \mathrm{m}$ & -623.3 & 0.8 & 37.98 & 0.08 & 7776,8 & 8535.5 & 16,9 \\
\hline 18930 & Plot5a & 405 & $<36>1,6 \mu \mathrm{m}$ & -668.3 & 0.8 & 33.45 & 0.08 & 8797,1 & 9898.5 & 19,2 \\
\hline 18912 & Plot5a & 433 & $<36>1,6 \mu \mathrm{m}$ & -110.4 & 1.5 & 89.69 & 0.15 & 874,1 & 759.5 & 13,4 \\
\hline 18913 & Plot5a & 433 & $<1,6 \mu \mathrm{m}$ & -104.5 & 1.6 & 90.29 & 0.16 & 820,5 & 709,0 & 14,2 \\
\hline
\end{tabular}

